\title{
HIGH ON THE HOG
}

\author{
Pig in the middle.
}

\section{BY SEAN DAVIDSON}

$\mathrm{S}$ omeone told me the other day that there's 185 industrial uses for a pig. So I guess that makes me number 186 . Which is kinda weird, 'cos until a few years ago, the closest I'd come to a real pig was riding my hog - my big, black, Harley Davidson '08 VRSCD Night Rod. Aww yeah! ... I was one with the machine, roaring down the highway, growling up the hills, grunting and snorting at the poncey Japanese bikes stopped at the lights. I practically lived on my hog. Couldn't separate us. Even after the crash. Not that I remember much about that. I remember the 'squeeeeeeall...' of the tyres as I took off from the lights, then the pigs behind me. The cops, I mean. And I remember a strange feeling of dislocation like I was somewhere floating, watching body and machine as we slammed into the road, scraping along making one hell of a racket ... once I would have said 'like a stuck pig' but I'm more considerate now. They said later it was like we'd been welded together, my leg fused with the chassis. Nothing they could do but cut us apart. Carve us up, like meat from the bone. I could use a few spare ribs, though, they said! Ha ha! They love their jokes, the paramedics. But gotta admit, they really saved my bacon.

I wasn't so familiar with the transplant scene back then. Of course I'd heard about human-to-human transplantation - that was old school, but it had run up against the predicted problem of supply and demand, then the real show-stopper: immune suppression. Without it, your new buddyorgan wouldn't stick around for long, but each new super-multi-extra-crossresistant bug that appeared took out another swathe of the old 'planters. "Rejection by an organ is not a rejection of you as a person," the support groups said, but still, it felt like more than just a slap in the face.

Xenotransplantation - that was the Holy Grail. And finally the obstacles (there had been many) were overcome with fully

$\rightarrow$ NATURE.COM

Discuss this story online at: go.nature.com/bd8b7r



humble pig's! Not just our hearts but our kidneys, livers, lungs - nearly everything... though they ran into some 'rejection at the patient level' when they tried it on with the trotters!

But I was too mashed up even for xeno. I knew it was bad when I woke, 'cos most of my body was missing. But I still wasn't ready for the shock of looking over, all dazed and confused, and there's Doug, mucking about

work: breathing, eating, digesting, filtering and pumping your blood, even ahem, urinating, et cetera."

"You've undergone 'holo-transplantation', he said. "That's transplantation of the whole animal," he added, as if I still hadn't got it.

Sometimes when we walk in the park it feels like I'm flying a kite in the shape of a pig. Other times it feels like he's flying me. We go for walks quite a lot. I never used to when I had my own legs - hated nature and dirt - but these days I really enjoy it. Electricity's a bit steep now, so Doug literally does the legwork, pulling my body along in our pig-chariot, but he's happy. I was worried, at first, that he'd resent working for the parasitic human grafted onto him, but he's become as attached to me as I am to him. I got us a great little bungalow flat to live in and ripped out all the floorboards so now it's full of the fresh smell of damp earth. We keep it clean though, I'd like to point out. A bit of mud is all right once in a while to cool down but that's not such an issue now he's got me, 'cos unlike pigs, of course, I can sweat. Just one of our many little shared benefits.

Turns out we like a lot of the same stuff. Corn, for instance. And rotten tomatoes. OK, that's probably a taste I've developed more recently but then I don't think I ever tried eating them back when I had my old stomach. Now Doug does the eating and when he eats rotten tomatoes we're in heaven! The doctors don't believe me, but you'd be amazed at how much you share in a blood relationship like this. I discovered that pretty quickly, the first time Doug and I left the hospital. The flashbulbs of the press freaked

in the sterilized mud in his pen next to me! Two long, thick, plastic tubes jumping between us: 'in' and 'out'. Not that I've got anything against pigs. In fact, you could say I've developed quite a connection. He must have sensed I was conscious then, because he suddenly looked around in surprise. I stared into his stunned-looking little blue eyes. That's all I remember of our first meeting.

Next time I woke, I was surrounded by white coats but I knew Doug was still there. "What's the bloody pig doing?" I yelled. "JR.16's sharing his blood with you," says the Doc. "From now on he'll do all the hard him out and the adrenaline! It pumped straight from him into me and before I knew it we were both jumping about like crazies!

So you see, that's why the doctor won't be seeing us again. Oh, I'm sure he's correct and this new technique will do away with the need for the pig, but there'll be another test subject. In the meantime we're locking the door, and he's not coming in.

Not by the hair on my chinny chin chin!

Sean Davidson is a cardiovascular researcher working in London who enjoys taking things to their illogical conclusions. 